\title{
Detection of human enteric viruses in water and shellfish samples collected in Sicily (Italy)
}

\author{
Giuseppa Purpari, Santina Di Bella, Francesca Gucciardi, Francesco Mira, Santino Barreca, Laura Di Paola, \\ Giusi Macaluso, Patrizia Di Marco \& Annalisa Guercio
}

Istituto Zooprofilattico Sperimentale della Sicilia “A. Mirri” Via G. Marinuzzi 3, 90129 Palermo, Italy

*Corresponding author, e-mail: macalusogiusi@gmail.com

ABSTRACT

KEY WORDS

Received 28.11.2019; accepted 19.12.2019; published online 20.12.2019

Proceedings of the 4th International Congress on Biodiversity "Man, Natural Habitats and Euro-Mediterranean Biodiversity", November 17th-19th, 2017 - Malta
Enteric viruses are responsible for foodborne and waterborne infections caused by contaminated food products and water, affecting a large number of people. Among the foods an important role is played by shellfish, on the ground that they can be eaten raw or undercooked. Data on food and water viral contamination in South of Italy are scarce and fragmentary. As illnesses result from the failure to control an hazard, the aim of this study was to detect the main pathogenic human enteric viruses in the environment, for evaluating the presence of viral contamination in shellfish and water samples collected in South of Italy (Sicily). The survey was conducted over a period of five years (2012-2016) on 16 water samples (sea waters, pipe waters and torrent water), and 72 fresh and frozen shellfishes from harvesting areas, restaurants, and markets during regional official control or checked at Veterinary Border Inspection Posts. Hepatitis A virus (HAV), GI and GII genogroup Norwalk virus (NoVs), Adenovirus and Rotavirus were detected by nucleic acid amplification (end-point and Real Time PCR/RTPCR) and sequence analysis. The most frequently detected viruses in shellfish were GI NoV $(16.7 \%)$ and HAV (18.0\%). Of the 16 water samples $12.5 \%$ were positive for GII NoV and $6.2 \%$ for RoV. Molecular surveillance of water and shellfish clearly demonstrated that human pathogenic viruses are widely found in aquatic environments and confirmed the role of bivalve molluscs as main reservoirs.

\section{INTRODUCTION}

Numerous viruses of human or animal origin are found in the environment and infect people by water and food: bivalve molluscs along with vegetables and prepared foods are classified by the World Health Organization as priority hazards (WHO, 2018). Most of these viruses belong to the families Adenoviridae, Caliciviridae, Hepeviridae, Picornaviridae and Reoviridae (Dubois et al., 1997;
Muscillo et al., 2001; Lodder \& de Roda Husman, 2005). These pathogens are routinely introduced into the environment through the discharge of treated and untreated wastes that can be transported through groundwater, estuarine water, seawater, and rivers (Okoh et al., 2010; La Rosa \& Muscillo, 2012; La Rosa et al., 2012). A succession of health alarms, "foodborne diseases" and "waterborne diseases", increasing the attention on food and water safety was decribed in the last decades (Le Guyader 
et al., 2000; Pintó et al., 2009; EFSA, 2011, 2016; Sánchez \& Bosch, 2016). Shellfish and water could play an important role in the determination of environmental contamination. Consumption of fish products, with particular reference to Edible Lamellibranch Molluscs (ELM), is a risk for human health because of their capacity to filter, accumulate and concentrate pathogens present in the contaminated water. Hepatitis A (HAV), Norovirus (NoV) and Rotavirus (RoV) and the emerging Hepatitis E (HEV) have been found in shellfish, especially mussels and oysters (Bellou et al. 2013). Viral waterborne disease outbreaks associated with contaminated drinking or recreational waters are reported worldwide, suggesting the contamination of aquatic environments (Kamel et al., 2011; Prado et al., 2012; La Rosa et al., 2015). Contaminated water could irrigate vegetables and retain enteric viruses on their surface (Petrinca et al., 2009; La Rosa et al., 2010a; Severi et al., 2015; Scavia et al., 2017; Iaconelli et al., 2016). HAV, NoV, Adenovirus $(\mathrm{AdV})$, multiple strains of (EV) (Echoviruses and Coxsackievirus) and HEV are enteric viruses associated with human wastewater (Lodder et al., 2005).
$\mathrm{EV}$ is able to contaminate and survive in brackish and probably saltwater and in shellfish (Patel et al., 2009).

Hepatitis A virus is highly resistant in the environment, and typically transmitted through raw shellfish or water (Pintó \& Bosch, 2013). The consumption of raw shellfish caused outbreaks in 19961997 and 2004 in southern Italian regions (Apulia and Campania) (Malfait et al., 1996). Iaconelli et al. (2015) assessed the occurrence of HAV in shellfish samples, detecting in $23.2 \%$ samples, 12 genotype IB and one genotype IA. La Rosa et al. (2017) investigated the spread of HAV in Italy through the monitoring of raw urban sewages and detected several variants with a prevalent IB strain having a countrywide distribution.

Norovirus can be classified into seven genogroups, GI to GVII (Vinjé, 2015; Zheng et al., 2006) with more than 30 genotypes within genogroups GI, GII, and GIV infecting humans (Kroneman et al., 2013). Several routes of NoV transmission have been identified in many welldocumented outbreaks. Foodborne transmission, including infected foodhandler, can play an important

\section{BIOMOLECULAR ASSAYS}

HAV RT-PCR

HAV Real Time RT-PCR

NoV RT-PCR

GI and GII NoVs Real Time

RT-PCR

Rotavirus Real Time RT-PCR

Adenovirus PCR
GeneAmp ${ }^{\circledR}$ RNA PCR Core Kit - Applied Biosystem

(Le Guyader et al., 1994)

UltraSense TM One-Step (Quantitative) qRT-PCR

System RNA kit - Invitrogen

(ISO/TS 15216-2:2013; Costafereda et al., 2006)

GeneAmp ${ }^{\circledR}$ RNA PCR Core Kit - Applied Biosystem

(Vinje e Koopman, 1996)

UltraSense TM One-Step (Quantitative) qRT-PCR

System RNA kit - Invitrogen

(ISO/TS 15216-2:2013; da Silva et al., 2007)

TaqMan Universal PCR Master Mix - Applied

Biosystem

(Freeman et al., 2008)

Taq PCR Core Kit - QIAGEN

(Formiga-Cruz et al., 2005) 


\begin{tabular}{|c|c|c|c|c|c|c|c|}
\hline Year & Matrix & N. Samples & $\begin{array}{l}\text { HAV } \\
\text { Pastilleserforal }\end{array}$ & $\begin{array}{l}\text { GINoV } \\
\text { Positiver Iotol }\end{array}$ & $\begin{array}{l}\text { GII NoV } \\
\text { Pastitive Total }\end{array}$ & $\begin{array}{l}\text { Adenovirus } \\
\text { Peatithes Toal }\end{array}$ & $\begin{array}{l}\text { Rotavirus } \\
\text { PositherToral }\end{array}$ \\
\hline \multirow{2}{*}{2012} & Shellfish & 11 & $3 / 11$ & $5 / 11$ & $0 / 11$ & $0 / 11$ & $0 / 11$ \\
\hline & Water & 1 & 1 & 1 & 1 & 1 & 1 \\
\hline \multirow{2}{*}{2013} & Shellfish & 27 & $10 / 27$ & $5 / 27$ & $3 / 27$ & $1 / 27$ & $0 / 27$ \\
\hline & Water & 6 & $0 / 6$ & $0 / 6$ & $0 / 6$ & $0 / 6$ & $0 / 6$ \\
\hline \multirow{2}{*}{2014} & Shellfish & 24 & $0 / 24$ & $2 / 24$ & $1 / 24$ & $1 / 24$ & $0 / 24$ \\
\hline & Water & 4 & $0 / 4$ & $0 / 4$ & $1 / 4$ & $0 / 4$ & $1 / 4$ \\
\hline \multirow{2}{*}{2015} & Shellfish & 2 & $0 / 2$ & $0 / 2$ & $0 / 2$ & $0 / 2$ & $0 / 2$ \\
\hline & Water & 1 & 1 & 1 & 1 & 1 & 1 \\
\hline \multirow{2}{*}{2016} & Shellfish & 8 & $0 / 8$ & $0 / 8$ & $0 / 8$ & $0 / 8$ & $0 / 8$ \\
\hline & Water & 6 & $0 / 6$ & $0 / 6$ & $1 / 6$ & $0 / 6$ & $0 / 6$ \\
\hline \multirow{2}{*}{ TOTAL } & Shellfish & 72 & $13 / 72$ & $12 / 72$ & $4 / 72$ & $2 / 72$ & $0 / 72$ \\
\hline & Water & 16 & $0 / 16$ & $0 / 16$ & $1 / 16$ & $0 / 16$ & $1 / 16$ \\
\hline
\end{tabular}

Table 2. Detection of enteric viruses from shellfish and water samples.

role. In a meta-analysis of NoV outbreaks in nursing homes, foodborne introduction was described for $7 \%$ and only $0.7 \%$ of outbreaks was reported to be foodborne, $28.5 \%$ as person-to-person, and $70.8 \%$ remained unknown or not mentioned (Petrignani et al., 2015). Several waterborne outbreaks have been described, with an indirect evidence of potential airborne transmission (such as in explosive vomiting occurred during the disease) ( $\mathrm{La}$ Rosa et al., 2012; Giammanco et al., 2014; Giammanco et al., 2018).

Rotaviruses infections are found worldwide. It is estimated to cause more than 200,000 deaths annually; in particular children are infected during the first 6-9 months of life (Soriano-Gabarró et al., 2006).

Human adenovirus (HAdV) are the only human enteric viruses to contain DNA. They are often detected with other human enteroviruses and/or hepatitis A virus in different environments (Puig et al., 1994; Pina et al., 1998). HAdV have been widely detected in wastewaters, surface waters, recreational waters as well as in treated and disinfected drinking water (Mena \& Gerba, 2009). For these reasons it has been proposed as indicator (for monitoring human faecal water contamination and efficacy of water purification) (La Rosa et al., 2010b).

Among the wide range of enteric viruses, four groups - HAV, NoV, RoV and AdV- were selected for this study due to their epidemiological significance as foodborne and waterborne pathogens (EFSA, 2011, 2016; La Rosa et al., 2012; Sánchez $\&$ Bosch, 2016). The objective was to assess the presence of HAV, GI and GII NoV, AdV and RoV in bivalve molluscs and environmental waters by end-point and real-time PCR/RT-PCR and sequence analysis.

\section{MATERIAL AND METHODS}

A total of 72 fresh and frozen shellfish and 16 environmental waters, were collected between 2012 and 2016. All the samples were screened for HAV, 
GI and GII NoV, AdV and RoV molecular detections.

\section{Sampling}

Shellfish samples were collected from restaurants and fish markets, from three harvesting areas in the province of Syracuse and five centers in Messina and during official control monitoring programs in Sicily. They consisted in different species: Mytilus galloprovincialis, Mytilus edulis, Tapes semidecussatus, Tapes decussatus, Ensis directus, Crassostrea gigas, and Venus verrucosa.

Water samples included brackish water from the mussel farming centre in Syracuse); pipe water from Santo Stefano di Quisquina, Agrigento, where a Norovirus outbreak had occurred in 2011 (Giammanco et al., 2014) and from the province of Catania where in May 2016 a NoV outbreak had occurred (Giammanco et al., 2018); water from a desalter and seawaters (water from Lampedusa island, Agrigento, where a HAV outbreak had occurred in 2014); torrent water from the province of Caltanissetta.

\section{Preparation of molluscs}

Each batch of mollusk sample consisted in $25 \mathrm{~g}$ of hepatopancreas homogenized with $0.05 \mathrm{M}$ glycine buffer ( $\mathrm{pH} 9.2)$ and processed with a double 1.5 M NaCl PEG8000 (final concentration of 12.5 $\%$ ) precipitation (Croci et al., 1999). A parallel extraction from $2 \mathrm{~g}$ of hepatopancreas was performed using treatment with a proteinase $\mathrm{K}$ solution, following the International Organization for Standardization (ISO) technical specification (ISO 15216-2:2013).

The samples were spiked with $10 \mu \mathrm{l}$ of titrated Mengovirus process control strain MC0 (1.6x104 TCID50/ml), to monitor extraction efficiency following the ISO 15216 guidelines.

\section{Preparation of water samples}

Water samples (10 litres each) were concentrated through a tangential ultrafiltration system (Sartoflow ${ }^{\circledR}$ Slice 200 Benchtop Crossflow System, Sartorius AG, Goettingen, Germany), using appropriate membranes (SG Hydrosart $10 \mathrm{kDa}$ ) pretreated with 3\% Beef Extract (BE) pH 7. Elution and recovery of viruses attached to the membranes employed 3\% BE pH 9.5 up to reduce the initial volume to $10-12 \mathrm{ml}$ with $\mathrm{pH} 7$ (Aulicino et al., 1993; Giammanco et al., 2014).

\section{Nucleic acid extraction}

The viral genomes (RNA and DNA) were extracted by using commercial kit based on the selective binding of nucleic acids to silica magnetic beads as described by the manufacturer $(\mathrm{Nu}-$ cliSENS ${ }^{\circledR}$ miniMAG extraction, bioMe'rieux Italia S.p.A., Rome, Italy). In order to compare the extraction results, for some samples, spin columns were also used, employing the QIAamp ${ }^{\circledR}$ Viral RNA Kit Mini Kit - QIAGEN (RNA), by varying the initial volume of the sample to be extracted (560 $\mu \mathrm{l})$ and the volume of the eluate $(100 \mu \mathrm{l})$.

\section{Molecular detection}

HAV, GI and GII NoV, RoV and AdV were detected by nucleic acid amplification (end-point and Real Time PCR/RTPCR) and sequencing.

Biomolecular assay amplification kits and references used in this study are shown in the Table 1.

The positive RT-PCR/PCR products obtained were purified using illustra ${ }^{\mathrm{TM}} \mathrm{GFX}^{\mathrm{TM}}$ PCR DNA and Gel Band Purification Kit (GE Healthcare) and sequenced (BMR Genomics, Padova, Italy). The raw forward and reverse $\mathrm{ABI}$ files obtained were aligned and assembled into a consensus sequence using MEGA 7 software and sequences submitted to BLAST analysis (http://blast.ncbi.nlm.nih.gov/ Blast.cgi).

\section{RESULTS}

Table 2 shows the results of the analysis. Of the 72 mollusc samples, 31 (43.0 \%) were positive for enteric viruses, showing a high positivity for HAV (18.0\%), NoV (16.7\% GI, 5.5\% GII). AdV was found in $2.8 \%$ of the molluscs. No RoV was found in shellfish.

The $13 \mathrm{HAV}$ positive shellfish were genotyped as HAV 1A (one sample) and HAV 1B (12 samples). The 12 GI NoV positive shellfish were classified in six different genotypes for GI NoV (GI.1, GI.2, GI.3 , GI.5, GI.6, GI.8) and three genotypes 
for GII NoV (GII.1, GII.2, GII.4). A single genotype was detected for Adenovirus (AdV40).

The recovery efficiency, determined on the process control Mengovirus, was $>1 \%$ for all the samples and thus results considered valid according to ISO 15216-2:2013.

Of the 16 water samples, 3 (18.7\%) were positive for enteric viruses. Two water samples (12.5\%) were positive for GII NoV (GII.2 and GII.4). The superficial freshwater sample were found positive for GII.4 and also for RoV. Data on RoV genotyping are not yet available. None of the other tested enteric viruses were detected in the water samples.

\section{DISCUSSION AND CONCLUSIONS}

Viruses are recognized as cause of foodborne and waterborne disease transmitted by the fecal-oral cycle. According to a report by European Food Safety Authority EFSA, enteric viruses were the most commonly detected $(20.4 \%)$ causative agent in foodborne outbreaks (EFSA, 2015). Among the main foods involved in the transmission of human enteric viruses are molluscs, fruits and vegetables irrigated with wastewater and/or washed with nonpotable water, contaminated drinking or recreational water.

Detection of enteric viruses in waters and contamination of aquatic environments have been reported by several studies worldwide (La Rosa et al., 2010a, b; Kamel et al., 2011; Prado et al., 2012; La Rosa et al., 2015; Osuolale \& Okoh, 2015). In Sicily an outbreak of gastroenteritis occurred in Agrigento during March 2011, and NoV was identified in water samples from the public water system (Giammanco et al., 2014); a NoV gastroenteritis outbreak at a seaside resort near Taormina (Mascali, Sicily) originated from municipal water distribution system in May 2016 (Giammanco et al., 2018).

Data on food, particularly shellfish and water viral contamination in South of Italy are poor; this study analyzed both matrices for a panel of enteric viruses and provided information on the presence of environmental contamination, chiefly in shellfish production areas, useful to better understand the circulation of viral pathogens able to infect humans in Sicily.

The study found an abundance of viruses in the samples investigated. In the total of the samples,
HAV showed the highest percentage of presence (14.8\%), followed by GI NoV (13.6\%), GII NoV (6.8\%). A low percentage was found for AdV $(2.8 \%)$ and $\operatorname{RoV}(1.1 \%)$. In particular, high positivity for HAV (18.0\%) was assessed in bivalve molluscan shellfish samples, investigated as sentinel of marine pollution. No HAV was detected in water samples. Most of water samples (12.5\%), object of the present study, were positive for GII NoV.

In the present study NoV was also detected in shellfish (16.7\% GI, 5.5\% GII). NoV repeatedly cause outbreaks either waterborne or associated with shellfish probably contaminated with human fecal material used as fertilizer (Müller et al., 2016).

The genetic heterogeneity of the viral strains from the positive Sicilian samples were particularly interesting, highlighting the presence of HAV IA and IB, six different genotypes of GI NoV (GI.1, GI.2, GI.3, GI.5, GI.6, GI.8) and of three genotypes of GII NoV (GII.1, GII.2, GII.4). A major single genotype, GII.4, has been associated with the vast majority of NoV-related outbreaks and sporadic cases of acute gastroenteritis (AGE) worldwide (Bok et al., 2009). A single genotype was detected for Adenovirus (AdV40). Data on RoV genotyping are not available.

Our findings clearly demonstrate the presence of human pathogenic virus in aquatic environmentsbe useful as a scientific support for informed risk assessment of foodborne and waterborne diseases and to implement and optimize virological controls in the food chain. For this purpose, an integrated "One Health" surveillance system is clearly needed to obtain molecular data on virus isolated from humans and the environment to rapidly understand possible future viral outbreaks and epidemics.

\section{REFERENCES}

Aulicino F.A., Patti A.M., Orsini P., Volterra L. \& Muscillo M., 1993. Concentrazione e recupero di enterovirus da campioni di acqua di mare: ultrafiltrazione tangenziale. L'Igiene Moderna, 100: 1416-1432.

Bellou M., Kokkinos P. \& Vantarakis A., 2013. Shellfishborne viral outbreaks: a systematic review. Food and Environmental Virology, 5: 13-23. https://doi. org/ 10.1007/s12560-012-9097-6 
Bok K., Abente E.J., Realpe-Quintero M., Mitra T., Sosnovtsev S.V. \& Kapikian A.Z., 2009. Evolutionary dynamics of GII.4 noroviruses over a 34-year period. Journal of Virology, 83: 11890-901. https://doi. org/ 10.1128/JVI.00864-09

Costafreda M.I., Bosch A. \& Pintò R.M., 2006. Development, evaluation, and standardization of real-time TaqMan reverse transcription-PCR assay for quantification of hepatitis A virus in clinical and shellfish samples. Applied and Environmental Microbiology, 72: 3846-3855. https://doi.org/10.1128/AEM.02660 $-05$

Croci L., De Medici D., Morace G., Fiore A., Scalfaro C., Beneduce F. \& Toti L., 1999. Detection of hepatitis A virus in shellfish by nested reverse transcription-PCR. International Journal of Food Microbiology, 48: $67-71$.

da Silva A.K., Le Saux J.C., Parnaudeau S., Pommepuy M., Elimelech M. \& Le Guyander F.S., 2007. Evaluation of removal of noroviruses during wastewater treatment, using Real-Time Reverse TranscriptionPCR: different behaviors of genogroups I and II. Applied and Environmental Microbiology, 73: 78917897. https:// doi.org/10. 1128/AEM.01428-07

Dubois E., Le Guyader F., Haugarreau L., Kopecka H., Cormier M. \& Pommepuy M., 1997. Molecular epidemiological survey of rotaviruses in sewage by reverse transcriptase semiNested PCR and restriction fragment length polymorphism assay. Applied and Environmental Microbiology, 63: 1794-1800.

EFSA 2011. Scientific opinion on an update on the present knowledge on the occurrence and control of foodborne viruses EFSA J, 9: 2190.

EFSA 2016. EU summary report on zoonoses, zoonotic agents and food-borne outbreaks 2015. EFSA J, 14: 4634 [231 pp.].

Formiga-Cruz M., Hundesa A., Clemente-Casares P., Albiñana-Gimenez N., Allard A. \& Girones R., 2005. Nested multiplex PCR assay for detection of human enteric viruses in shellfish and sewage. Journal of Virological Methods, 125: 111-118. https://doi.org/ 110.1016/ j.jviromet. 2005.01.009

Freeman M.M., Kerin T., Hull J., McCaustland K. \& Gentsch J., 2008. Enhancement of Detection and Quantification of Rotavirus in Stool Using a Modified Real-Time RT-PCR Assay. Journal of Medical Virology, 80: 1489-1496. https://doi.org/10.1002/ jmv. 21228

Giammanco G.M., Di Bartolo I., Purpari G., Costantino C., Rotolo V., Spoto V., Geraci G., Bosco G., Petralia A., Guercio A., Macaluso G., Calamusa G., De Grazia S., Ruggeri F.M., Vitale F., Maida C.M. \& Mammina C., 2014. Investigation and control of a Norovirus outbreak of probable waterborne transmission through a municipal groundwater system. Jour- nal of Water and Health, 12: 452-464. https://doi. org/10.2166/wh.2014.227

Giammanco G.M., Bonura F., Urone N., Purpari G., Cuccia M., Pepe A., Li Muli S., Cappa V., Saglimbene C., Mandolfo G., Marino A., Guercio A., Di Bartolo I., De Grazia S., 2018. Waterborne Norovirus outbreak at a seaside resort likely originating from municipal water distribution system failure Epidemiology and Infection, 146, 879-887. https://doi.org/10.1017/S095026881800081X

Iaconelli M., Purpari G., Della Libera S., Petricca S., Guercio A., Ciccaglione A.R., Bruni R., Taffon S., Equestre M., Fratini M., Muscillo M. \& La Rosa G., 2015. Hepatitis A and E Viruses in Wastewaters, in River Waters, and in Bivalve Molluscs in Italy. Food and Environmental Virology, 7: 316-324. https/doi. org/10.1007/s12560-015-9207-3

Iaconelli M., Divizia M., Della Libera S., Di Bonito P. \& La Rosa G., 2016. Frequent Detection and Genetic Diversity of Human Bocavirus in Urban Sewage Samples. Food Environmental Virology, 8: 289-295. https/doi.org/10.1007/s12560-016-9251-7

Iaconelli M., Muscillo M., Della Libera S., Fratini M., Meucci L, De Ceglia M., Giacosa D. \& La Rosa G., 2017. One-year Surveillance of Human Enteric Viruses in Raw and Treated Wastewaters, Downstream River Waters, and Drinking Waters. Food Environmental Virology, 9: 79. https://doi.org/10.1007/ s12560-016-9263-3

ISO/TS 15216-2:2013. Microbiology of food and animal feed - Horizontal method for determination of hepatitis A virus and norovirus in food using real-time RTPCR - Part 2: Method for qualitative detection. Geneva, Switzerland: ISO.

Kamel A.H., Ali M.A., El-Nady H.G., Deraz A., Aho S., Pothier P. \& Belliot G., 2011. Presence of enteric hepatitis viruses in the sewage and population of Greater Cairo. Clinical Microbiology \& Infection, 17: 1182-1185. https://doi.org/10.1111/j.1469-0691. 2011.03461.x

Kroneman A., Vega E., Vennema H., Vinjé J., White P.A., Hansman G.., 2013. Proposal for a unified norovirus nomenclature and genotyping. Archives of Virology, 158: 2059-2068. https://doi.org/10.1007/s00705013-1708-5

La Rosa G., Iaconelli M., Pourshaban M., Muscillo M., 2010a. Detection and molecular characterization of noroviruses from five sewage treatment plants in central Italy. Water Resources, 44: 1777-1778.

La Rosa G., Pourshaban M., Iaconelli M. \& Muscillo M., 2010b. Quantitative real-time PCR of enteric viruses in influent and effluent samples from wastewater treatment plants in Italy Annali dell'Istituto Superiore di Sanità, 46: 266-273. https://doi.org/10.4415/ ANN_10_03_07 
La Rosa G., Fratini M., Spuri Vennarucci V., Guercio A, Purpari G. \& Muscillo M., 2012. GIV noroviruses and other enteric viruses in bivalves: a preliminary study. New Microbiologica, 35: 27-34.

La Rosa G. \& Muscillo M., 2012. Molecular detection of viruses in water and sewage. In: Cook N. (Ed.), Viruses in food and water: Risks, surveillance and control. Woodhead Publishing Series in Food Science, Technology and Nutrition.

La Rosa G., Della Libera S., Iaconelli M., Donia D., Cenko F. \& Xhelilaj G., 2015. Human bocavirus in children with acute gastroenteritis in Albania. Journal of Medical Virology, 88: 906-910. https://doi.org/10. 1002/jmv.24415

La Rosa G., Sanseverino I., Della Libera S., Iaconelli M., Ferrero V.E.V., Barra C.A. \& Lettieri T., 2017. The impact of anthropogenic pressure on the virological quality of water from the Tiber river, Italy. Letters in Applied Microbiology, 65: 298-305. https://doi.org/ 10.1111/lam.12774.

Le Guyader F., Dubois E., Menard D. \& Pommepuy M., 1994. Detection of Hepatitis A Virus, Rotavirus and Enterovirus in naturally contaminated shellfish and sediment by Reverse Transcription-Seminested PCR. Applied and Environmental Microbiology, 60: 3665 3671.

Le Guyader F., Haugarreau L., Miossec L., Dubois E., Pommepuy M., 2000. Three-year study to assess human enteric viruses in shellfish. Applied and Environmental Microbiology, 66: 3241-3248.

Lodder W.J. \& de Roda Husman A., 2005. Presence of noroviruses and other enteric viruses in sewage and surface waters in The Netherlands. Applied and Environmental Microbiology, 71: 1453-1461. https://doi.org/10.1128/AEM.71.3.1453-1461.2005

Malfait P., Lopalco P., Salmaso S., Germinario C., Salamina G., Quarto M., Barbuti S., Cipriani R., Mundo A. \& Pesole G., 1996. An outbreak of Hepatitis A in Puglia, Italy, 1996. Euro surveillance: bulletin europeen sur les maladies transmissibles. European communicable Disease Bulletin, 1: 33-35. https://doi.org/10.2807/esm.01.05.00144-en.

Mena K.D. \& Gerba C.P., 2009. Waterborne adenovirus. Review of Environmental Contamination and Toxicology, 198: 133-167. https://doi.org/10.1007/9780-387-09647-6 4

Muscillo M., La Rosa G., Marianelli C., Zaniratti S., Capobianchi M.R., Cantiani L. \& Carducci A., 2001. A new RT-PCR method for the identification of reoviruses in seawater samples. Water Res., 35: 548549. https://doi.org/10.1016/s0043-1354(00)00282-7

Müller L., Rasmussen L.D., Jensen T., Schultz A.C., Kjelsø C., Barnadas C., Sigsgaard K., Larsen A.R., Widstrup Jensen C., Jeppesen S., Uhrbrand K., Hove N., Mølbak K. \& Ethelberg S., 2016. Series of
Norovirus Outbreaks Caused by Consumption of Green Coral Lettuce, Denmark, April. PLoS Curr. 2016 Oct 4;8. pii: ecurrents.outbreaks. $115761 \mathrm{~d} 5 \mathrm{~d}$ $6 \mathrm{de} 6 \mathrm{a} 8 \mathrm{bc} 7 \mathrm{dd} 4 \mathrm{~b} 41 \mathrm{f0f5f} 142$.

Okoh A.I., Sibanda T. \& Gusha S.S., 2010. Inadequately treated wastewater as a source of human enteric viruses in the environment. International Journal of Environmental Research and Public Health, 7: 2620 2637. https://doi.org/10.3390/ijerph7062620

Osuolale, O. and Okoh, A., 2015. Assessment of the Physicochemical Qualities and Prevalence of Escherichia coli and Vibrios in the Final Effluents of Two Wastewater Treatment Plants in South Africa: Ecological and Public Health Implications. International journal of environmental research and public health, 12: 13399-13412. https://doi.org/10.3390/ ijerph121013399

Patel M.M., Hall A.J., Vinjé J. \& Parashar U.D., 2009. Noroviruses: a comprehensive review. Journal of Clinical Virology, 44: 1-8. https://doi.org/10.1016/j. jcv.2008.10.009

Petrignani M., van Beek J., Borsboom G., Richardus J.H. \& Koopmans M., 2015. Norovirus introduction routes into nursing homes and risk factors for spread: a systematic review and meta-analysis of observational studies. Journal of Hospital Infection, 89: 163178. https://doi.org/10.1016/j.jhin.2014.11.015

Petrinca A.R., Donia D., Pierangeli A., Gabrieli R., Degener A.M., Bonanni E., Diaco L., Cecchini G., Anastasi P. \& Divizia M., 2009. Presence and environmental circulation of enteric viruses in three different wastewater treatment plants. Journal of Applied Microbiology, 106: 1608-1617. https://doi. org/10.1111/j.1365-2672.2008.04128.x

Pina S., Puig M., Lucena F., Jofre J. \& Girones R., 1998. Viral pollution in the environment and in shellfish: human adenovirus detection by PCR as an index of human viruses. Applied and Environmental Microbiology, 64: 3376-3382.

Pintó R.M. \& Bosch A., 2013. Advances in Understanding of Hepatitis A Virus as a Food and Waterborne Pathogen and Progress With Vaccine Development. In: Viruses in Food and Water: Risks, Surveillance and Control. Edited by Nigel C. UK: FERA, pp. 349357.

Pintó R.M. \& Costafreda M.I., Bosch A., 2009. Risk assessment in shellfish-borne outbreaks of hepatitis A. Applied and Environmental Microbiology, 75: 73507355. https://doi.org/10.1128/AEM.01177-09

Prado T., Fumian T.M., Miagostovich M.P. \& Gaspar A.M., 2012. Monitoring the hepatitis A virus in urban wastewater from Rio de Janeiro, Brazil. Transactions of the Royal Society of Tropical Medicine and Hygiene, 106: 104-109. https://doi.org/10.1016/j.trstmh. 2011.10.005 
Puig M., Jofre J., Lucena F., Allard A., Wadell G. \& Girones R., 1994. Detection of adenoviruses and enteroviruses in polluted waters by Nested PCR amplification. Applied and Environmental Microbiology, 60: 2963-2970.

Istituto Superiore di Sanità Analytical methods for water intended for human consumption according to the Italian Legislative Decree 31/2001. In: Bonadonna L. \& Ottaviani M. (Eds.), Microbiological methods. iv, 204 p. Rapporti ISTISAN 2007; 07/5, pp. 144-160

Sánchez G. \& Bosch A., 2016. Survival of enteric viruses in the environment and food. In: Goyal S.M. \& Cannon J.L. (Eds.), Viruses in Foods, Food Microbiology and Food Safety. Springer International Publishing. Basel, pp. 367-392.

Scavia G., Alfonsi V., Taffon S., Escher M., Bruni R., De Medici D., Di Pasquale S., Guizzardi S., Cappelletti B., Iannazzo S., Marina Losio N., Pavoni E., Decastelli L., Ciccaglione A.R., Equestre M., Tosti M.E. \& Rizzo C., 2017. A large prolonged outbreak of hepatitis A associated with consumption of frozen berries, Italy, 2013-14. Journal of Medical Microbiology, 66: 342-349. https://doi.org/10.1099/jmm. 0.000433

Severi E., Verhoef L., Thornton L., Guzman-Herrador B.R., Faber M., Sundqvist L., Rimhanen-Finne R., Roque-Afonso A.M., Ngui S.L., Allerberger F., Baumann-Popczyk A., Muller L., Parmakova K., Alfonsi V., Tavoschi L., Vennema H., Fitzgerald M., Myrmel M., Gertler M., Ederth J., Kontio M., Vanbockstael
C., Mandal S., Sadkowska-Todys M, Tosti M.E., Schimmer B., O'Gorman J., Stene-Johansen K., Wenzel J.J., Jones G., Balogun K., Ciccaglione A.R., O’Connor L., Vold L., Takkinen J. \& Rizzo C., 2015. Large and prolonged food-borne multistate hepatitis A outbreak in Europe associated with consumption of frozen berries, 2013 to 2014. Eurosurveillance, 20 (29): 21192. https://doi.org/10.2807/1560-7917. ES2015.20.29.21192

Soriano-Gabarró M., Mrukowicz J., Vesikari T. \& Verstraeten T., 2006. Burden of Rotavirus Disease in European Union Countries. The Pediatric Infectious Disease Journal, 25: S7-S11. https://doi.org/10. 1097/01.inf.0000197622.98559.01

Vinjé J. \& Koopmans M.P., 1996. Molecular detection and epidemiology of small round- structured viruses in outbreaks of gastroenteritis in the Netherlands. Journal of Infectious Diseases, 174: 610-615.

Vinjé J., 2015. Advances in laboratory methods for detection and typing of norovirus. Journal of Clinical Microbiology, 53: 373-381. https://doi.org/10.1128/ JCM.01535-14

WHO, 2018. Who Estimates Of The Global Burden Of Foodborne Diseases-Foodborne Disease Burden Epidemiology Reference Group 2007-2015.

Zheng D.P., Ando T., Fankhauser R.L., Beard R.S., Glass R.I. \& Monroe S.S., 2006. Norovirus classification and proposed strain nomenclature. Virology, 346: 312-323. 